\title{
DOI: 10.7596/taksad.v9i2.2500
}

Citation: Holubenko, N., \& Demetska, V. (2020). Category of Modality Through the Prism of Multipole Approaches in the Modern Translation Theory. Journal of History Culture and Art Research, 9(2), 303317. doi:http://dx.doi.org/10.7596/taksad.v9i2.2500

\section{Category of Modality Through the Prism of Multipole Approaches in the Modern Translation Theory}

\author{
Nataliia Holubenko' ${ }^{1}$, Vladislava Demetska
}

\begin{abstract}
This paper presents a brief theoretical overview of the dimensions and some of the main features of the contemporary approaches to translation studies tracing the development of the paradigm shift concept in translation from linguistic-oriented to communicatively- and cognitively-based perspectives. The emergence of the developmental ideas in translation theory proves that modern scientists continue to draw a parallel between translation and other intellectual activities, phenomena, and systemic entities. The purpose of the study is to shed light on the contemporary approaches to translation of the last decades of the $21^{\text {st }}$ century such as the cognitive translational theory of situated translation, a narrative approach to translation studies, and an adaptive approach to translation emphasizing their relevance and applicability for theory and practice of translation. Besides, the study accentuates the relevancy of the selected approaches to analyze the category of modality in translation with the accent on solving the problems of cognitive background, narrative environment, adaptivity of implicit modality in translation.
\end{abstract}

Keywords: Translation theory, Translation approach, Translation methods, Paradigm shifts, Category of modality.

\footnotetext{
${ }^{1}$ Ph.D. in Philology, Lecturer, Kyiv National Linguistic University, Department of English and German Philology and Translation, Ukraine, 03680. E-mail: n.irgovtsiy@gmail.com

${ }^{2}$ Dr. in Philology, Professor, Kyiv National Linguistic University, Department of English and German Philology and Translation, Ukraine, 03680. E-mail: vdemetskaya@gmail.com
} 


\section{Introduction}

In today's far-reaching world scientists from different translation schools seek to find and develop new theories for better understanding and improvement of translation studies. Accordingly, enhancing the development of new methodology, aspects, models, and approaches in translation theory has long been a primary role of researchers in this field around the world. Therefore, since the 1990s, there has been a variety of linguistic and non-linguistic approaches to the analysis of translation that have proposed various models and theories of translation. The burgeoning literature on theory and practice of translation and interpretation has touched almost every discipline of human activity, encompassing literature, linguistics, history, sociology, psychology, rhetoric, physics, and some others. This largely proves the status of translatology as an interdisciplinary field.

The main focus of our discussion restricts us to describe a number of the latest new or most representative approaches to translation for the last decades of the $21^{\text {st }}$ century. Besides, this study is an attempt to shed some light on various philosophical arguments towards the cross-disciplinary character of translation study as a discipline, and the importance of ontology and epistemology in the development of new approaches and methods. We are inclined here to state that the following approaches offer a means to consider a category of modality from a translational perspective and to highlight the methodology of its investigation. Thus, the objectives of this study are as follows: 1) to survey the newly developed approaches to translation such as the narrative approach to translation by Mona Baker, cognitively-oriented situated translation, and adaptive approach. The emerging of the new concepts and approaches can be justified not by the fact that the general idea concerning the divergences between a source text (ST) and target text (TT) has remained the same, but rather by the supposition that the attitudes towards the general guideline of the approaches have changed significantly; 2) to provide insight into the category of modality through the prism of analyzed theoretical approaches. In translation theory, there are many theoretical models that at different times were effectively applied by various scientists to the subject of research. These new concerns in translation theory changed due to shifts of paradigms that laid the basis for the enrichment of its perceptions. That is why, the paradigm shift broadens the scope of translation transferring its focus from text to culture, purpose, and mind, so the central role is dedicated to the inner world of human beings. Translation studies continuously bring new theoretical and methodological developments. The discussion is aimed to reveal that different paradigms of translation studies have different views on translation, especially in the cases of modality transcoding.

\section{Methodology}

The theoretical insight into the research approaches to the problematics of translation studies requires the appliance of general scientific methods, among which are synthesis, analysis, theoretical observation, which allow deepening the linguistic, narrative, cognitive, and cross-cultural ideas of translation through the prism of the category of modality. Besides, the comparative analysis is used to highlight the different aspects of modality from each of the approaches perspective. It is the category of modality which proves the relevance of the described scientific attitudes to the challenges of modern translation studies.

\section{Results and discussion}

The influence of external factors on the formation of a certain identity caused by the constant interest of researchers in the fields of philosophy, linguistics, transformational grammar, psychology, anthropology, ethnography, cultural studies, and the like became an indispensable part of translation theory. One cannot deny that it is impossible to create a universal model to meet all the demands of researchers in the field of translation. Moreover, each model gives only an approximate description of the process or phenomenon, and different models reflect different properties of the translation process. One argument in support of this lies in the ability of the target text to explicitly or implicitly 
represents the source text in a way that correlates with the function of the model or approach of translation in the corresponding socio-cultural society.

As J. Holmes states, "[i]n other situations, the paradigms or models fail to produce sufficient results, and researchers become aware that new methods are needed to approach the problem" (1988). This is the first point that indicates the extent to which scientists tend to develop new methods and approaches in translation studies. The second point touches on the establishment of new channels of communication between researchers of other updated approaches and their colleagues of previous theories, and the establishment of the so-called 'new disciplinary utopia' named by J. Holmes. It means "a new sense of a shared interest in a common set of problems, approaches, and objectives on the part of a new grouping of researchers" (Ibid.). By the way, as W. O. Hagstrom (1965) has pointed out that these new channels of communication and the developed disciplinary utopia "make it possible for scientists to identify with the emerging discipline and to claim legitimacy for their point of view when appealing to university bodies or groups in the larger society" (p. 123).

Therefore, in the following section, we will focus in detail on models that would determine the direction of evolutionary progress in the field of translation, reflect norms of acceptability and canons of translation.

\section{Paradigm shifts in the translation studies as a scientific revolution}

Translation studies is considered to be a discipline that has gone a long way to get its own methodology, models, and approaches. Hurtado (2001, p. 131) classifies five approaches to translation studies: the linguistic approach, the main representatives of which are Catford, Vinay and Darbelnet; the textual approach, whose main representatives are Reis, Neubert, Hatim and Mason; the cognitive approach with such representatives as Bell, Gutt; the communicative and sociocultural approach represented by Snell-Horby, Hermans, Toury, Evan-Zohar, Lefevre; and the philosophical and hermeneutic approach, whose representatives are Robins, Venuti, Ladmiral.

According to Kuhn (1970), "a paradigm shift is a change from one way of thinking to another. It's a revolution, a transformation. It just does not happen, but rather it is driven by agents of change" (p. 10). Additionally, a paradigm is a result of some scholars' achievements characterized by two major aspects: 1) the achievement is sufficiently unprecedented to attract an enduring group of adherents away from competing models of scientific activity; 2) the achievement is sufficiently open-ended to leave all sorts of problems for the redefined group of practitioners to solve (Ibid.).

The rapid growth of translation studies during the second half of the $20^{\text {th }}$ century has led to the domination of the linguistic-oriented science of translation, which substituted the word-for-word method. At that time the concept of equivalence has come into the scientific world thanks to $\mathrm{E}$. Nida (1964) who proved his thought by the statement that "the relationship between receptor and message should be substantially the same as that which existed between the original receptors and the message" (p. 159).

Later scientists began to pay more attention to function but not the language equivalence (linguistic approach). The best representatives of the so-called functionalist approach are K. Reiss and $\mathrm{H}$. Vermeer. It is $\mathrm{H}$. Vermeer who created the skopos theory, the focus of which is on the text types and text purpose. In 1990, Bassnett and Lefevre published Translation, History, and Culture and developed the idea of a cultural shift in translation. The cultural approach paid much attention to the importance of culture in translation and its influence on adequate translation of the ST and culture to the $\pi$ and culture. The notions of culture and language (including translation) are inseparable and interconnected, as exactly shown in Lotman's theory that "no language can exist unless it is steeped in the context of culture..." (1978, p. 211-232). One of the typical examples of this approach is a polysystem theory developed by an American-Dutch scholar Evan-Zohar. In his theory, the notion of 
system is understood as a structure with different levels elements of which are closely interacted with one another. He proves the concept of a system as a dynamic network of principles and procedures. Indeed, Evan-Zohar (2010) states that:

Polysystem theory is a continuation of dynamic functionalism. Its concept of an open, dynamic and heterogeneous system is perhaps more able to encourage the emergence of favorable conditions to allow the discovery power of relational thinking (p. 37).

The U.S. scholar and translator Edwin Gentzler (2008) in his book Translation and Identity in the Americans: New Directions in Translation Theory outlines that "the next turn in translation studies should be a social-psychological one, expanding a functional approach to include social effects and individual effects" (p. 180). According to his definition of translation as a social and psychological activity, this leads to the emergence of a new paradigm in translation studies named social and psychological one. Furthermore, the shift surely develops and broadens the scope and methodology of translation studies. It is the mind and insight world of a person that is in the center of the investigation in this field. It opens new perspectives for the study of translation, as it began to be considered more widely comparing with linguistics and literary issues.

\section{The cognitive translational theory of situated translation}

Cognitive scientists do not consider the mind as a black box in comparison to a psychological perspective. The modern cognitive approach takes its roots from other disciplines such as psychology, first, neuroscience, philosophy, linguistics, anthropology, and others. Hanna Risku gives an example based on Campbell and Wakim (2007) that psycholinguistic research on bilingualism has had a major effect on translation studies (and even stronger effect on interpreting studies), while text comprehension and production research has provided important discourse processing concepts, due to Dijk and Kintsch (1983). All these disciplines bring some methodology to the study of cognition, understanding of which is a prerequisite for the realization of translation from a cognitive perspective, which tries to answer a few questions concerning the work of translator's mind: How do translators understand, interpret and create meaning in texts they work with? How do they use the strategies and choices to render properly the text? How does his/her inner world influence the choice in translating? What influences his way of thinking and understanding and how does it work? It follows, that a cognitive approach tends to make clear the work of mental processes and cognitive behavior in translation.

This shift of focus from the product to the process of translation has led to the 'cognitive turn' in translation studies (Siever, 2010, p. 341) and to the central question of 'what happens in the minds of translators' (Krings, 1986). A similar development can be observed within cognitive translation studies starting with the general notion of 'ideal translator' (Kade, 1968) with his linguistically-oriented 'translation algorithms' and ending with 'the real translator' in construction of cognitively-oriented theories of translation. It follows that the cognitive translation studies have risen from the theory of Situated Translation (Risku, 2010) where the individual situational factors of the translator and his working environment are of paramount importance.

The major proponent of a cognitive linguistic approach in translation studies is Halverson (2003; 2010) who works within the framework of Langacker's cognitive grammar (1987) and who is the author of the term 'cognitive translation studies'. The scholar's main investigation shares Halverson's central claim that "cognitive theory of translation is built on cognitive theories of language" (2003; 2010).

Krüger justifies that various technical texts to be translated may have different degrees of technicality, which are derived from three communicative configurations within the dimensions of 
subject matter competence: expert-to-layperson, expert-to-semi-expert and expert-to-expert communication (Vargas, 2005). By the way, Krüger (2014) assumes that "these communicative configurations correlate with the degree of technicality of the corresponding texts, with the knowledge required to understand these texts becoming more and more extensive (ranging from little or no specialized to very detailed theoretical and applied scientific/technical knowledge)" (p. 79). In terms of cognitive linguistics, the shared knowledge within a separate discourse community is modeled with the concept of common ground between two or more people (Taylor, 2003; Langacker, 1987), which Clarks (1996) defines as "the sum of their mutual, common and joint knowledge, beliefs and suppositions" (p. 93).

By the way, Krüger (2014) justifies that the common ground concept represents the communicators' knowledge in a specific cultural or discourse community:

The common ground concept was shown to constitute a sound theoretical tool for modeling the shared specialized knowledge of participants in scientific and technical discourse. The actual organization of this knowledge implicitly underlying the discourse of specific discourse communities can be modeled within cognitive semantics (p. 82).

It is worth mentioning that the different communicative configurations and the different degrees of technicality of scientific and technical texts reflect different configurations of communal common ground between the authors and the readers of such texts (Krüger, 2013). The linking of the common ground concept with the three communicative configurations can be described in the following graphics:

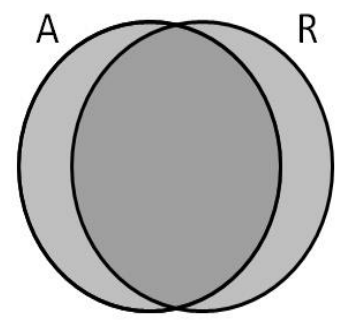

Expert-to-expert

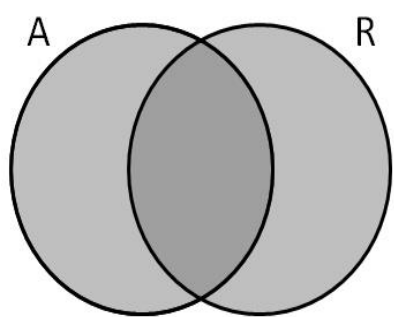

Expert-to-semi-expert

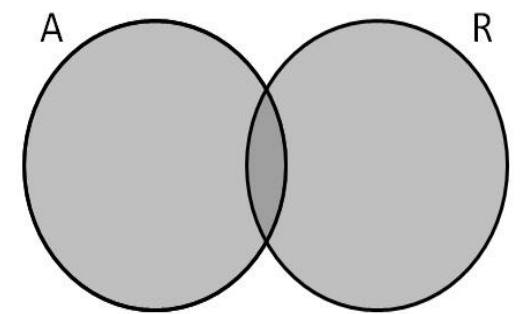

Expert-to-layperson

The first picture shows the large intersection of the two corresponding circles, which ensures a high degree of shared knowledge between author and reader. The two other following schemas expert-to-semi-expert and expert-to-layperson communication describe smaller and smaller common ground between discourse participants (as represented by a lower degree of intersection of the circles).

Along with the abovementioned principles of the translation of technical texts, the huge prospect for accumulating all the significant linguistic aspects of translations is devoted greatly to the concept of linguistic construal and the various construal operations developed by Croft and Cruse (2004) and Langacker (2008). The construal operation involves "the selection of conceptual content for linguistic presentation, as well as its arrangement into ... foreground vs. background (Langacker, 2008, p. 57). Moreover, such notions as 'sequential scanning' and 'summary scanning' (Langacker, 1987, p. 144-145; Croft \& Cruse, 2004, p. 53-54) are the very good example of Langacker's construal operation of 'dynamicity' having ability to combine the linguistic construal and the linguistic dimension of the translation of scientific and technical texts. 


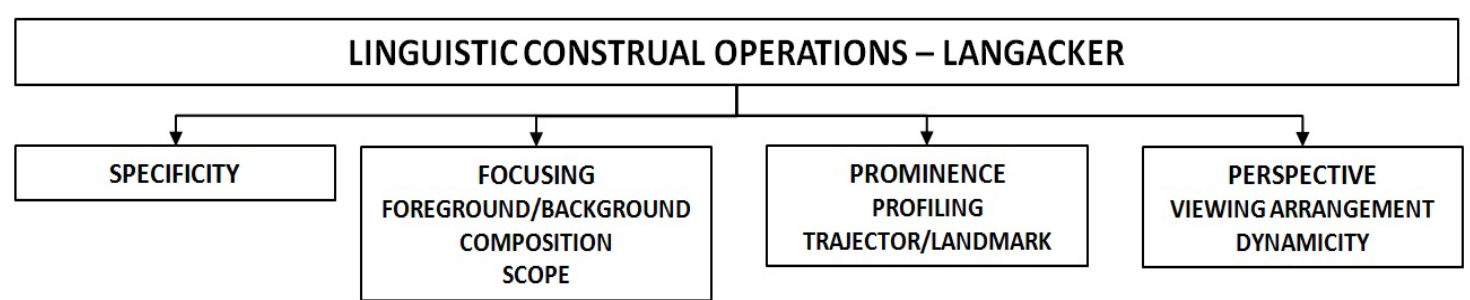

Krüger justifies this "sequential scanning and summary scanning could be used to capture differences in the degree of nominalization/verbalization between SL and TL registers" (2013). By the way, Croft and Cruse's (2004, p. 63-64) construal operation of 'structural schematization' as a part of the higher level construal operation could be used to describe how STs and TTs differ in "the conceptualization of the topological, meronomic and geometrical structure of entities and their components" (Ibid., p. 63). It follows that Croft and Cruse (2004, p. 46) also group their linguistic construal operations under four main constituents:

\begin{tabular}{|c|c|c|c|}
\hline \multicolumn{3}{|c|}{ LINGUISTIC CONSTRUAL OPERATIONS - CROFT AND CRUSE } \\
\hline $\begin{array}{c}\text { ATTENTION/SALIENCE } \\
\text { SELECTION } \\
\text { SCOPE }\end{array}$ & $\begin{array}{c}\text { JUDGEMENT/COMPARISON } \\
\text { CATEGORIZATION (FRAMING) } \\
\text { SCALAR ADJUSTMENT } \\
\text { DYNAMIC }\end{array}$ & $\begin{array}{c}\text { PERSPECTIVE/SITUATEDNESS } \\
\text { VIEWPOINT } \\
\text { FIGURE/GROUND }\end{array}$ & $\begin{array}{c}\text { CONSTITUTION/GESTALT } \\
\text { STRUCTURAL SCHEMATIZATION } \\
\text { FORCE DYNAMICS } \\
\text { RELATIONALITY }\end{array}$ \\
\hline
\end{tabular}

This overview suggests that a detailed investigation of Langacker's and Croft and Cruse's linguistic construal operations concerning their applicability to linguistic aspects of the translation of scientific and technical texts should indeed be a fruitful and worthwhile endeavor. Moreover, the mentioned concepts and the various construal operations cover such linguistic aspects of the translation of scientific and technical texts as explicitness/implicitness paying special attention to the nominalization and verbalization tendencies in translation.

All these can be applied not only to the texts of scientific and technical discourse but to that of other non-literary texts such as college textbooks on politology (political science), history, etc. Politology as the branch of social science concerned with theory, description, analysis and prediction of political behavior, political systems and politics broadly-construed reveals, first of all, the ideology of a definite nation which comes to a great problem in translation. The ideological signaling of a textbook on political science is realized through explicit/implicit nature of its modality which has to be adequately represented in translation. And in the case of expert-to-expert translation there is almost no translation challenges since this translation variant keeps the experts cognitively beyond the ideological influence, because they are mainly interested in the model of this textbook, or, to put it in plain words, - how this textbook is written within the other linguistic and cultural tradition.

It is another matter altogether to translate this text type within the configurations of expertto-semi-expert and expert-to-layperson communication, as far as the modality of ideological influence will cause a problem in translation. Indeed, "[m]odality is the soul of the sentence. There is no utterance without modality" (Bally, 1995), and in its broad sense modality expresses the relationship between the author and his/her target audience (Carter et al., 1997, p. 143). The orientation of modality can be "subjective, objective, explicit, or implicit; its value can be either high or law; and its polarity can be either direct or transferred" (Moindjie, 2015, p. 14). Apparently, a textbook seems to present objective and explicit character of modality used in it, especially dealing with historic facts and other common places. However, the most challenging from the point of view of modality realization should be the fragments of the author's interpretation of these facts, for here the most essential is 
the implicit modality which reflects not only an author's point of view, but rather his/her system of values which to much extent shows the worldview of the whole culture.

On the whole, cognitively-oriented approach to the translation of scientific and technical texts attempts to answer the question to what extent the various theoretical components of the cognitive linguistics can be applied in modeling different contextual and textual aspects of translation. Special attention in this context is given to the concept of common ground and the cognitive-linguistic notion of linguistic construal used to model implicit knowledge and relevant linguistic aspects of the translation from a cognitive perspective.

\section{A narrative approach to translation studies by Mona Baker}

A few decades ago Mona Baker has published an article Translation and Conflict: A Narrative Account (2006) where she has focused attention on two impediments to the development of translation studies, such as social and narrative theory. This made a great impetus for researchers around the world in applying socio-narrative theory to translation study, with her ideas extended to many other fields of investigation. Therefore, research has found that narratives developed in medicine, psychology, and psychoanalysis shift towards history, philosophy, anthropology, rhetoric, law, politics, and education. Correspondingly, scientists from a wide range of disciplines successfully study narrative applying it to their investigations. Likewise, today scholars in translation studies are also engaged with narrative theory and use above mentioned Mona Baker's work as an example of its application to new areas of research. Narratives that take their roots in literature are studied in translation studies from the point of view, first of all, of a typology of narratives, the importance of narrators and temporary narrators, and the combination and interrelationship of sociological and narrative approaches.

All in all, it is Mona Baker (2006) who initiated the application of the narrative in translation postulating that narratives do not only represent, but constitute the world; they are an indispensable part of everything happening around us. They are the stories we unfold and present to make sense of our lives and to provide a reason for our actions. They are not limited to a particular genre or single texts but "cut across time and texts" (Ibid., p. 12) and constitute facts, events, and even elements around us. Baker discusses four kinds of narratives (ontological, public, conceptual and metanarrative), eight features of narrative (temporality, relationality, causal emplotment, selective appropriation, particularity, genericness, normativeness and narrative accrual), and the notion of framing as "an active strategy that implies agency" $(2006$, p. 6). That is, the author is mainly concerned with the roles of narratives during translation and interpreting in situations of violent political conflict and how narratives and translated ones are used by different mass media "to legitimize their version of events" (Ibid., p. 1). From this point of view, it is interesting to examine the translation of modern expressions between the pair of languages where the first expresses modality mostly grammatically while the second one - lexically. In this context Badran (2001) shows that Arabic modal verbalization in political discourse may be manipulated in translation.

By the way, Baker argues that translators should realize their role in society as peacemakers promoting and circulating narratives and discourses of various types. Hence, the author investigates how original and translated narratives are interpreted by different kinds of mass media postulating that translators are temporary narrators. But there are some unclear cues regarding the notion of the narrator. This term is taken from literature and means a person who tells the story and may or may not participate in the action that can benefit or harm the story. This follows that while interpreting the information told by narrator may be changed by the translator due to his beliefs and even knowledge. Here raises one question which Baker didn't take into account: how different kinds of the narrator (first person, second person and third person) influence the faithfulness of the representation of the real facts and how these aspects are conceptualized due to mentioned facts in the minds of translators 
acting as temporary narrators? This largely influences the interpretation of different kinds of mass media.

While Baker uses expanded approach to narrative theory and its relevance to translation, her follower Sue-Ann Harding (2012) "offers a textual analysis and detailed case study that functions as a testing ground for both the applicability of narrative theory to, and the investigation of, a sample of online media reportage" (p. 288). Moreover, S. Harding investigates and analyses the main constituents of narratological concepts such as text, storyline, narrator, anachronism, retroversions, actors, characters, place, and space which are textually bound and are formed based on verbal and nonverbal signs.

Thus, Baldo's (2008) study Translation as Re-Narration in Canadian-Italian Writing investigates a trilogy of novels by Italian-Canadian author Nino Ricci that describes the lives of one Italian family before and after migration to Canada. Drawing on poststructuralist narratological understandings of plot, focalization, and voice, Baldo explores the novelist's use of codeswitching (between English and Standard Italian or dialect) and how codeswitching passages are negotiated in the Italian translation of the novels (Harding, 2012, p. 288).

Boeri (2009) adopts a socio-narrative approach in his research Babels, the Social Forum and the Conference Interpreting Community: Overlapping and Competing Narratives on Activism and Interpreting in the Era of Globalisation. In social theory, particularly in the work of Somers (1997) and Somers and Gibson (1994) narrative is conceived as the principal and inescapable mode by which we experience the world (Baker, 2014, p. 6). That is, "everything we know is the result of numerous crosscutting storylines in which social actors locate themselves" (Somers \& Gibson, 1994, p. 41). They are the stories we tell about our previous experience in the world we live in. Consequently, in social theory the main point how narratives are constructed and impact our lives lies not on their structural makeup nor their textuality, but preferably on (a) the types or dimensions of narrative that mediate our overall 'take' on the world, and (b) the features that distinguish a narrative from a story or chronology of events (Baker, 2014, p. 6). But for translation scholars, it is necessary "to supplement the social theory approach to the narrative with textual methods of analysis to offer a productive application of narrativity within translation studies" (Ibid.).

In translation studies today we deal with a master (or meta) narratives defined by Somers and Gibson (1994) as such "in which we are embedded as contemporary actors in history... (p. 61). Our sociological theories and concepts are encoded with aspects of these master-narratives - Progress, Decadence, Industrialization, Enlightenment, etc". It follows that the translator is an honest intermediary who performs translation for goodness, peace, justice, and progress enabling dialogue between different cultures and nations. This statement explores the idea that the point of view of a translator, his attitude to the events, i.e. his modality can influence the narrative of the text in translation. Besides, this very approach gives the opportunity to examine and evaluate both the implicit modality of an author and that of a translator in the way how point of view shapes interpretation of narratives, how an author experiments with the types of modality to create point of view, and how the target audience may determine whether a narrator (an author, a translator) is reliable. In the first place this is a case of media translation especially that of different kinds of media reports from the battle zones like in the Near East and in the East of Ukraine. If we assume that the narrative in translation may change or shift the target audience's perspective on the world, that is the translator who creates the modality choosing the appropriate equivalent to the lexical element with, for example, implicit modality like in the pairs "separatist - militiamen (pro-Russian fighter)", "keeker (spier) - spy". Presumably, it is the translator' modality reflected in a $\Pi$, which actively engages with and makes the audience respond to the events within the context of the TT, and in the context of our world. 


\section{An adaptive approach to translation}

The skopos theory, developed by Vermeer in the 1970s, that was previously mentioned, has accentuated the communicative purpose in translation. It has largely changed the source-text orientation, moving towards target-text oriented views to make a translation sound natural not only due to lexico-semantic and grammatical means but paying special focus to the situational context.

According to Byrne (2012, p. 8), who discusses equivalence-based vs. functionalist approaches, equivalence focuses on recreating the ST in some form. Here, the huge potential is paid to the process of creating the $\Pi T$ taking into account such factors as the purpose of the translation or target reader expectations. A good example of such strong linguistically focused equivalence conceptions would be Catford's (1965) theory of translation shifts. With the rise of text linguistics, these highly reductionist notions of equivalence were generally discarded in favor of more functionally oriented approaches that placed a stronger focus on the communicative character of translation (Siever, 2010, p. 55).

While in these approaches there is still a strong relationship between a translation and its source text, the source text ceases to be the sole guiding principle for the creation of a target text, and factors of the wider communicative situation can be incorporated (Krüger, 2014). Hence, Koller (2011) considers that his five equivalence relations of denotative, connotative, text-normative, pragmatic, and formal equivalence highlight the multidimensional character of a text and the fact that a ST and its translation can only be equivalent concerning a certain parameter or dimension (p. 218). However, the shift of importance of translation from textual (linguistic) towards communicative level has played the greatest role in the development and discussion of pragmatic adaptation that was highlighted by Vinay and Darbelnet (1995) in the following statement: "if a translator systematically refuses to adapt, it will eventually lead to a weakening of a target text" (p. 41). Accordingly, this point of view clarifies the interrelation of the adaptation and translation process invigorating the relatedness not only of the ST and $\Pi$ T but the source and the target audience as well. This was further proved by Julie Sanders (2006) who defines adaptation as a breakthrough which "easily comprehensible to target audience via the process of approximation and updating", aiming to bring the STs and TTs to a "shorter cultural and temporal distance" (p. 19).

The point of view of Vinay, Darbelnet, and Sanders due to the communicative nature of adaptation as an integral part of the translation process is supported by Yves Gambier and Henrik Gottlieb. The scholars claim that with the rapid development of science there is "no such border which translation can cross to become adaptation" (Gambier \& Gottlieb, 2001, p. 56) postulating their judgment that "labeling of any text produced by a translator as an adaptation is often a hasty personal judgment" (Gambier \& Gottlieb, 2001, p. 34). By the way, this is proved by the statement that "asking a translator to create an easily comprehensible text using no cultural, pragmatic or any other kind of adaptation seems unrealistic" (Ibid.).

Moreover, later Laurence Raw (2012) also points out the important role of adaptation in translation:

Whether it's consciously carried out by a translator or not, successful adaptation allows (or even forces) the target readers to discover the text in a way that suits its aim, ensures the optimal reception experience, or simply promotes understanding of a specific message (p. 26).

The notion of pragmatic adaptation was first introduced by the German linguist Albrecht Neubert (1968) which is considered by him as the process of text adaptation "to the needs of the target language audience" (p. 34).

According to Vehmas-Lehto (2002), there are four types of pragmatic adaptation: addition that means adding a new element of any kind (e.g. a punctuation mark, a word, a phrase, a clause) or supra- 
segmental feature (e.g. italics, bold print); omission refers to deletion of the abovementioned elements; substitution as a replacement of some elements of the text to be adopted by others; change of order that refers to rearrangement of elements of any kind and size (p. 100). More or less, it is worth mentioning that these types of pragmatic adaptation may happen only on the textual level. Besides this, Vehmas-Lehto adds that pragmatic adaptation includes various extra-textual factors of the ST and TT, among which are time, place, and participants of communication. Moreover, Panu Kosonen supports the position of Vehmas-Lehto that pragmatic adaptation is the "modification of the source text to produce the text which conforms to the needs of a new language environment" (Kosonen, 2011, p. 63).

Hatim and Mason (1997) suggest that pragmatics is "the domain of intentionality or the purposes for which utterances are used in real contexts" (p. 222). Moreover, Hicky (1998) points out that pragmatics studies what language-users mean, as distinct from what their language means, the rules and principles governing their use of language, over and above the rules of language itself, grammar or vocabulary, and what makes some uses of language more appropriate than others in certain situations (Hicky, 1998, p. 4). Besides this, Vehmas-Lehto $(2005$, p. 99) mentions another key aspect of pragmatic adaptation. The scholar postulates that it is a solution to pragmatic translation problems that arise from situational contexts. The term 'translation problem' was defined by Nord (1997) in the following way:

Contrary to the translation difficulties encountered by an individual translator in their specific translation situation (for example, an unfamiliar word which is not in the dictionary), translation problems are regarded as the problems which have to be solved by the translator in the translation process in order to produce a functionally adequate target text and which can be verified objectively or at least intersubjectively (Nord, 1997, p. 141).

Nord (2005) distinguishes four types of translation problems: a pragmatic translation problem that arises from the contrast between the situations in which ST is used and the TT is produced (e.g. the audience-orientation of a text or deictic references to time and place); convention-related translation problems that deal with the differences in behavior conventions between the source and the target culture; linguistic translation problems concerning the structural differences between the source and the target language; text-specific translation problems dealing with particular features of the source text (e.g. translation of various stylistic devices) (p. 167).

However, it is worth mentioning that during the processes of translation and pragmatic adaptation the translator has to solve the abovementioned pragmatic translation problems. This is maybe achieved by the use of some translation strategies. Thus, Chesterman and Wagner put forward the following pragmatic strategies to achieve the desired effect in pragmatic adaptation:

- Cultural filtering (referred to naturalization, domestication of the source-language culturespecific items or an opposite procedure known as exoticization, foreignization).

- Explicitness change (changes towards explicitation or implicitation of the source text information).

- Information change (the edition or omission of the source target information to meet the requirements of the reader).

- Interpersonal change (changes affecting the degree of emotiveness and involvement).

- Illocutionary change (changes in speech act).

- Coherence change (changing the logical arrangement of information in the text).

- Partial translation (summary translation, transcription). 
- Visibility change (changes concerning the authorial presence or foregrounding of the translator presence).

- Trans-editing (total re-editing of the source text).

- Other pragmatic changes (covering layout or dialect) (Chesterman \& Wagner, 2002).

The notion of adaptation in translation is in the focus of the scientific attention of such Ukrainian scholars as V. Demetska, O. Kalnychenko, O. Khavkina, O. Podminohina, T. Volkova.

The consensus of scientific interpretations of the concept of 'adaptation' shows that adaptation becomes well-known as the 'stepdaughter' of translation science. The adaptive model of the translation and adaptive translation theory are an indispensable part of translation editing, translation in general and the theory of communication. As the communication theory considers the problems of adapting a certain message within the same culture to different addressees, that is why, from this point of view, adaptation is a branch of translation science. By the way, adaptation causes a complete modification of the text which is not recognized by most scientists as translation.

V. Demetska (2008) defines adaptation as "a type of translation with the dominant pragmatic guidelines referred to the expectations and stereotypes of the recipient language speakers and culture". The difference between the translation-adaptation and the translation-reproduction, as well as the free reproduction of texts based on the various types of intertext, is that the translationadaptation involves the comparison and validation of the original text, provided focus on the linguistic and cultural priorities of the recipient. The degree of proximity/distance from the original text can vary for different types of adaptive texts.

Adaptive translation texts are texts based on adaptive translation strategies. The adaptive strategy of the translation is directed on 1) primary use of language and cultural models of the recipient and 2) distinct pragmatic orientation of target texts to the audience.

Pragmatic and adaptive text-type potentials form the basis for classifying pragmatic types of text. According to these criteria, the classification of pragmatic types of texts includes vocabulary entries, textbooks, speeches (political speech, sermon) and advertising texts. Translation of the pragmatic types of texts from one culture into another presupposes the stereotypes and expectations of the recipient, which in turn leads to the choice of translation strategies in favor of reproductive and/or adaptive strategies as mentioned before.

Adaptive and reproductive strategies are mostly applicable while dealing with the modality transferring in translation. It is commonplace that "theories a propos of modality do not differ in the semantic perception of modality. However, they differ in terms of terminology and approach" (Moindjie, 2015, p. 15). Besides, it is stated that while epistemic modality views language as "information", deontic modality - as "action" (Palmer, 2001). The recent investigations show that the researchers mainly are interested in rendering explicit epistemic, deontic, and dynamic modality (Palmer, 2001; Nuyts, 2001; Baker, 1992; Farghal, 2016). However, the certain accent should be paid to the analysis of modality rendering in "modernizations" of temporally "old" texts, with a focus on why and how their modality was changed. In this context, it seems to be justified mentioning the TTs of Shakespeare "Hamlet" which are chronically distant from that of the original. Thus, the modality of Prince Hamlet of the $17^{\text {th }}$ century is rather opposite to that of Hamlet of the $21^{\text {st }}$ century in the Ukrainian adaptive version by Yurii Andrukhovich (2008), although they both tell the same story. In other words, the engaging with adaptation helps to analyze the ways the modality in translation may manipulate with a $T T$ in an innovative way.

\section{Conclusion}

Translation as a kind of inter-linguistic and intercultural communication has a multidimensional character and can accordingly be assessed from different points of view. First, the 
focus is on the conformity of the translated text with the original, and, second, it is a means of establishing the communicative, known as its pragmatic adequacy.

Traditionally, the research object of translation studies is language(s), but in modern society, it has transformed into human activity in different cultural contexts. As methods and approaches from the diversity of disciplines are appropriate for studying translation as a product and process, translation studies is known to be as an interdisciplinary field. It follows that different approaches and models of linguistics, pragmatics, discourse analysis, sociolinguistics, culture studies, communication studies, and cognitive studies were adapted to translation studies.

The paper traces the origins and the development of the translation concepts from its beginning in the middle of the $20^{\text {th }}$ century to the communicatively- and cognitively-oriented aiming to show how old concepts change over time and give rise to the new gateway of research.

The translation scholars elaborated a cognitively-oriented approach to the translation of scientific and technical texts. This is an attempt to answer the question to what extent the various theoretical components of the cognitive linguistics can be applied in modeling different contextual and textual aspects of scientific and technical translation. Special focus in this context is paid to the concept of common ground and the cognitive-linguistic construal used to model implicit knowledge and relevant linguistic aspects of scientific and technical translation from a cognitive perspective. To be more exact, the application of cognitive linguistics provides the modeling of different textual and contextual aspects of translation among which the modality transference takes its own place. After all, this approach applies not only the product-based accounts of translation but also puts the greatest emphasis on the translation process research, taking into consideration the cognitive expectancy of the target audience of different kinds.

Mona Baker qualifies that today's world is narrative; everything we encounter is narrative too. Narratives that take their roots in literature are studied in translation studies from the point of view, first of all, of a typology of narratives, the importance of narrators and temporary narrators, and the combination and interrelationship of sociological and narrative approaches. In this context the translator has to identify the author's language techniques in shaping modality and to render it adequately depriving the target audience from shifting its view of the world.

The findings of adaptive approach reveal that translation does not take place in a vacuum, but is greatly affected by various extralingual factors, one of the most important parameters of which is readership. Pragmatic adaptation is targeted at the purpose of the text to be conveyed in the target language in the best acceptable natural bringing texts to "shorter cultural and temporal distance" (Sanders, 2006, p. 19). By the way, basing on the discourse and communication translation model, it is put forward a methodology to be applied in translation analysis of the adaptive texts. Consequently, the choice of an adaptive approach depends on pragmatic and adaptive text-type potentials, a type of modality revealed as well as the translator's role, extralingual factors, and target-language means.

All in all, having analyzed the abovementioned approaches, one can conclude that each of them has made a major contribution to the theory and practice of translation. But there is one thing to be mentioned. The interface between translation theory and other fields of research such as cognitive linguistic and pragmatics turned out to be a very fruitful one for the ability of certain theoretical insights to yield not only into the linguistic/textual but also into the wider contextual dimensions of the translation. The thorough examination of this interface is prominent not only for the theory and practice of translation but to other research fields as well. Above all, it looks as if not only cognitive linguistics and pragmatics have important issues to say about translation but translation as an authentic academic field of language can also make a contribution to the theoretical standpoints of these subjects. That is why the discussed and described mutual benefits should be thoroughly investigated and expanded in future studies. 


\section{References}

Badran, D. (2001). "Modality and ideology in translated political texts." Nottingham Linguistic Circular 16: 47-61.

Baker, M. (1992). In other words: A coursebook on translation. London: Routledge.

Baker, M. (2006). Translation and Conflict: A Narrative Account. London: Routledge.

Baker, M., \& Saldanha, G. (2009). Routledge Encyclopedia of Translation Studies. London \& New York: Routledge.

Baldo, M. (2008). "Translation as Re-Narration in Italian-Canadian Writing: Codeswitching, Focalisation, Voice and Plot in Nino Ricci's Trilogy and its Italian Translation." Ph.D. diss., University of Manchester, UK.

Bally, Ch. (1955). General Linguistics and Questions of the French Language. Moscow.

Bassnett, S. (1996). Translation Studies. London: Routledge.

Bassnett, S., \& Lefevre, A. (1990). Translation, History, and Culture. London: Printer Publishers.

Boeri, J. (2009). "Babels, the Social Forum and the Conference Interpreting Community: Overlapping and Competing Narratives on Activism and Interpreting in the Era of Globalisation." Ph.D. diss., University of Manchester, UK.

Byrne, J. (2012). Scientific and Technical Translation Explained. A Nuts and Bolts Guide for Beginners. Manchester: St. Jerome.

Campbell, S., \& Wakim, B. (2007). "Methodological questions about translation research: A model to underpin research into the mental processes of translation". Target 19, no. 1: 1-19.

Carter, R., Goddard, A., Reah, D., Sanger, K., \& Browning, M. (1997). Working with Texts: Core Introduction to Language Analysis. London and New York: Routledge.

Catford, J. C. (1965). A Linguistic Theory of Translation. An Essay in Applied Linguistics. London: Oxford University Press.

Chesterman, A., \& Wagner, E. (2002). Can theory help translators? A dialogue between the ivory tower and the wordface. Manchester: St. Jerome Publishing.

Clark, H. H. (1996). Using Language. Cambridge: Cambridge University Press.

Croft, W., \& Cruse, D. A. (2004). Cognitive Linguistics. Cambridge: Cambridge University Press.

Demetska, V. (2008). "Theory of translational adaptation". Doctoral diss., the Taras Shevchenko National University of Kyiv, Ukraine.

Dorofeyeva, M. S. (2017). "Translation Synergetics of Specialized Texts". Ph.D. diss., the Taras Shevchenko National University of Kyiv, Ukraine.

El-Daly, H. M. (2015). "Paradigm Shifts in Translation Studies: Focus on Linguistic, Cultural, Social and Psychological Turns." Sino-US English Teaching 12, no. 5: 369-386.

Evan-Zohar, I. (2010). Papers in Culture Research. Tel Aviv: Unit of Culture Research, Tel Aviv University.

Farghal, M., \& Al-Hamly, M. (2016). "Modality with Past Time Reference in English-into-Arabic Fiction translation." Journal of Arts and Social Sciences, 3: 69-81. DOI: 10.24200/jass.vol7iss2pp69-81

Gambier, Y., \& Gottlieb, H. (2001). (Multi)media Translation: Concepts, Practices, and Research. Amsterdam and Philadelphia: John Benjamins.

Gentzler, E. (2008). Translation and identity in the Americans: New directions in translation studies. London \& New York: Routledge. 
Hagstrom W. O. (1965). "The Differentiation of Disciplines", in Barnes, 121-125 (reprinted from Hagstrom, The Scientific Community [New York: Basic Books,1965], 222-226).

Halverson, S. (2003). "The Cognitive Basis of Translation Universals", Target 15, no. 2: 197-241.

Halverson, S. (2010). "Cognitive Translation Studies: Developments in theory and method". In Translation and Cognition, edited by G. Shreve and E. Angelone, 349-369. Amsterdam: John Benjamins.

Harding, S. A. (2012). "Socio-narrative theory in translation studies." Target 24, no. 2: 286-309.

Hatim, B. (2001). Teaching and researching translation. Harlow: Pearson Education Limited.

Hatim, B., \& Mason, I. (1997). The translator as a communicator. London: Routledge.

Hatim, B., \& Munday, J. (2004). Translation: An advanced resource book. London \& New York: Routledge.

Hickey, L. (1998). The pragmatics of translation. Clevedon: Multilingual Matters.

Holmes, J. (1988). "The Name and Nature of Translation Studies". In Translated: Papers on Literary Translation and Translation Studies. Amsterdam: Rodopi, 66-80.

Hurtado Albir, A. (2001). Traducción y traductología : Introducción a la traductología. Catedra. Madrid.

Kade, O. (1968). "Kommunicationswissenschaftliche Probleme der Translation". In: Grundfragen der Übersetzungswissenschaft. Leipzig: Verlag Enzyklopadie, 3-19.

Knežević, B., \& Bogunović, I. (2011). "Modals and modality in translation: A case study based approach". Jezikoslovlje, 12.

Koller, W. (2011). Einführung in die Übersetzungswissenschaft. Tübingen: Francke.

Kosonen, P. (2011). Pragmatic Adaptation: Skeptics vs. Creationists. Jyväskylä: University of Jyväskylä Publishing.

Krings, H. P. (1986). Was in den Köpfen von Übersetzern vorgeht. Eine empirische Untersuchung zur Struktur des Übersetzungsprozessesan fortgeschrittenen Französisch-lernern. Tübingen: Narr.

Krüger, R. (2013). “A Cognitive Linguistic Perspective on Explicitation and Implicitation in Scientific and Technical Translation". Trans-kom6, no. 2: 285-314.

Krüger, R. (2014). Exploring the Interface Between Scientific and Technical Translation and Cognitive Linguistics: The Case of Explicitation and Implicitation. School of Humanities, Languages and Social Sciences, University of Salford. https://pdfs.semanticscholar.org/16ef/c85c03dfb395b4f3a16890b05df64c78cfc7.pdf

Kuhn, T. (1970). The structure of scientific revolutions. London: The University of Chicago Press, Ltd.

Langacker, R. W. (1987). Foundations of Cognitive Grammar I: Theoretical Prerequisites. Stanford: Stanford University Press.

Langacker, R. W. (2008). Cognitive Grammar. A Basic Introduction. Oxford: Oxford University Press.

Lotman, J., \& Uspensky, B. (1978). “On the semiotic mechanism of culture”. New literary history 9, no. 2: 211-232.

Moindjie, M. A. (2015). "The Function of Modality in Translation." International Journal of Comparative Literature \& Translation Studies 3, no. 2: 11-24. DOI: 10.7575/aiac.ijclts.v.3n.2p.11

Munoz Martin, R. (2010). "On paradigms and cognitive translatology" in Translation and Cognition, edited by G. M. Shreve and E. Angelone, 169-187. Amsterdam, Netherlands: John Benjamins.

Neubert, A. (1968). Pragmatische Aspekte der Übersetzung. Leipzig: Verlag Sprache und Literatur.

Nida, E. (1964). "Principles of Correspondence" in The translation studies reader, edited by L. Venuti, 126-140. London: Routledge. 
Nord, C. (1997). Translating as a Purposeful Activity. Functionalist Approaches Explained. Manchester: St. Jerome.

Nuyts, J. (2001). Epistemic modality, language and conceptualization. Amsterdam: John Benjamins.

Palmer, F. (2001). Mood and modality. Cambridge: Cambridge University Press.

Pym, A. (1992). Translation and text transfer: an essay on the principles of intercultural communication. Frankfurt um Main: Peter Lang.

Raw, L. (2012). Adaptation, Translation, and Transformation. New York: Continuum.

Risku, H. (2010). "A cognitive scientific view on technical communication and translation: Do embodiment and situatedness really make a difference?" Target 22, no. 1: 94-111.

Sanders, J. (2006). Adaptation and Appropriation. London. New York: Routledge.

Shakespeare, W. (2008). Hamlet, Prince of Denmark. [In Ukrainian]. Translated by Yurii Andrukchovich. Kyiv: A-BA-BA-HA-LA-MA-HA.

Siever, H. (2010). Übersetzen und Interpretation. Die Herausbildung der Übersetzungswissenschaft als eigenständige wissenschaftliche Disziplin im deutschen Sprachraum von 1960 bis 2000. Frankfurt am Main.

Snell-Hornby, M. (1988). Translation Studies: An integrated approach. Amsterdam: John Benjamin.

Somers, M. (1997). "Deconstructing and Reconstructing Class Formation theory: Narrativity, Relational Analysis, and Social Theory." In Reworking Class, edited by John R. Hall, 73-105. Ithaca \& London: Cornell University Press.

Somers, M., \& Gibson, G. (1994). "Reclaiming the Epistemological 'Other': Narrative and the Social Constitution of Identity." In Social Theory and the Politics of Identity, edited by Craig Calhoun, 37-99. Oxford, UK and Cambridge, USA: Blackwell.

Stolze, R. (2011). Übersetzungstheorien. Eine Einführung. Tübingen: NarrVerlag.

Taylor, J. R. (2002). Cognitive Grammar. Oxford: Oxford University Press.

Van Dijk, T. A., and Kintsch, W. (1983). Strategies of discourse comprehension. New York, NY: Academic Press.

Vargas, C. (2005). "A Pragmatic Model of Text Classification for the Compilation of Special-Purpose Corpora". In Thistles. A Homage to Brian Hughes. Essays in Memoriam. Vol. 2, edited by Yus Francisco, 295-315. Alicante: University of Alicante.

Vehmas-Lehto, I. (2002). Copying or communication? An introduction to translation theory. Helsinki: Oy Finn Lectura Ab.

Venuti, L. (2008). The translator's invisibility: A history of translation ( $2^{\text {nd }}$ ed.). London \& New York: Routledge.

Vermeer, H. (1989). "Skopos and commission in the translational activity". In The translation studies reader, edited by L. Venuti, 221-232. London: Routledge.

Vinay, J. P., \& Darbelnet, J. (1995). Comparative Stylistics of French and English. Philadelphia. John Benjamins.

Ward, L. F. (1993). Pure Sociology. A Treatise on the origin and spontaneous development of society. New York: Macmillan.

Zimnyaya, I. (1993). "A psychological analysis of translation as a type of speech activity". In Translation as a social activity. Russian and Bulgarian perspectives, edited by P. Zlateva, 87-100. New York: Routledge. 